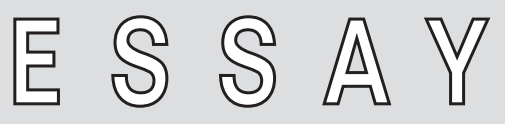

Finn Hansson

\title{
Studenteroprøret på sociologi. Fagkritik og pædagogisk fornyelse ${ }^{1}$
}

\section{Studenteroprør på Sociologisk Institut}

Studenteroprøret i København i 1968 startede med store demonstrationer på Frue Plads med krav om medbestemmelse over undervisning og fagindhold. Det førte til besættelse af en række af universitetets institutter og af rektor Mogens Fogs kontor, hvor billeder af studenter, der ryger rektors cigarer og drikker hans portvin, dominerede medierne. Der er imidlertid en anden del af studenteroprøret, som ikke fik samme opmærksomhed i medierne. Hvad skete der med kravene om at få en samfundskritisk og relevant uddannelse, der kunne aktivere de studerende?

I bogen »1968 - studenteroprør og undervisningsrevolution« (Hansson 2018) har jeg forsøgt at vise, hvorledes de oprørske studenter fik gennemtvunget radikale ændringer i datidens autoritære undervisningssystem. Bogen viser, hvorledes studenteroprøret gennem aktioner og deltagelse i råd og nævn var i stand til at reformere eller måske snarere revolutionere den traditionelle universitetsundervisning med forelæsninger og individuel vejledning. Resultatet blev, at gruppearbejde, organiseret omkring projekter, hurtigt blev indført i en række studieordninger og allerede i 1972/73 også valgt af Undervisningsministeriet som pædagogisk model for de to nye universitetscentre, RUC og AUC. De hårde kampe forudsatte en konstant mobilisering af de studerende, en mobilisering, som det i længden ikke var muligt at fastholde. Langsomt mistede de studerende initiativet, og reformpolitikken gik tilbage 
til politikerne, den professionelle universitetsledelse og embedsværket i Undervisningsministeriet. Det betød, at de radikale reformer, som de aktionerende studenter havde tilkæmpet sig, blev begrænset og reformeret. Allerede i slutningen af 1970'erne begyndte også en langsom, men ret systematisk tilbagerulning af de demokratiske landvindinger, som de studerende havde fået med Styrelsesloven. ${ }^{2}$

Bogen slutter med nogle betragtninger om udviklingen i undervisningsformerne på universiteterne efter perioden fra 1968 til 1972. Bogens analyse viser, at de studerendes kampe var drivkraften i de omfattende pædagogiske reformer på universiteterne. De efterfølgende politiske begrænsninger af Styrelsesloven reducerede ikke bare de studerendes muligheder for at fastholde de tilkæmpede studiereformer, men også den innovationskraft, som de studerende dengang stod for dengang. En vigtig side af studenteroprørets kampe blev imidlertid kun i begrænset omfang behandlet i bogen. Kampene i 1968 og årene derefter var ikke kun en kamp for nye undervisningsformer, men også en kamp for, at indholdet i fagene skulle være relevant, så de studerende kunne arbejde med den samfundskritik, som oprøret også stod for. Bogens fokus var dog primært på kampene om at få indført de nye undervisningsformer, som de aktionerende studenter kæmpede for.

I dette essay vil jeg følge op på analysen i bogen og med et eksempel fra et institut vise, at de studerende ikke blot reformerede undervisningsformerne, men også indholdet i studierne. Hvad skete der derefter med kravene om samfundskritiske studier? Det er vigtigt at være opmærksom på, at studenterbevægelsens succes med at forandre universiteterne foregik $i$ en periode, hvor det borgerlige danske samfund var under voldsom forandring. Den moderne velfærdsstat var under opbygning, og der var en hidtil uset politisk åbenhed for reformer, både under borgerlige og socialdemokratiske regeringer. $\mathrm{Og}$ den politiske venstrefløj var måske ikke så stærkt repræsenteret i Folketinget som i dag, men havde tætte forbindelser til de mange sociale bevægelser på det tidspunkt; kampen mod atomkraft, ungdomsoprøret, studenteroprøret, Thylejren, Christiania.

Denne politiske interesse for reformer er en vigtig del af baggrunden for, at studenterbevægelsen kunne mobilisere de studerende også $\mathrm{i}$ årene efter 1968. Studenterbevægelsen blev inddraget i universitetspolitikken, både lokalt og i ministerielt regi, og det betød en væsentlig indflydelse på en række reformer. Eksempelvis fik Danske Studerendes Fællesråd i 1970 mulighed for at udpege repræsentanter til de arbejdsgrupper, der skulle planlægge de nye universitetscentre, RUC og AUC. Den hurtige sejr over det elitære universitet indebar imidlertid også en stigende politisk modsætning i studenterbevægelsen, en modsætning mellem fastholdelse af kravene fra 1968 om radikale samfundsforandringer overfor muligheder for konkret indflydelse på reformer. Reformarbejdet kom i stigende grad til at dominere politikken, og den sam- 
fundskritiske fagkritik i de enkelte studier fik efterhånden en mindre fremtrædende plads i studenterpolitiken.

Godt 50 år efter studenteroprøret er det tydeligt, at studenterbevægelsen for sent blev opmærksom på, at de hurtige sejre også skyldtes, at der i det politiske system dengang var stærke kræfter, der ønskede universitetsreformer. Universiteterne skulle tilpasses det moderne samfund og producere de nødvendige kandidater med relevante kvalifikationer til opbygning af den kommende velfærdsstat (Hansson 2018, s. 75-82, Hansen 2017 s. 231-363). Den aktive deltagelse i reformarbejdet betød, at centrale dele af studenterbevægelsen i stigende omfang blev integreret i reformarbejde, mens en række af de aktive studerende på de enkelte uddannelser forsat kæmpede for de oprindelige krav om samfundskritiske studier. På sigt begrænsede deltagelsen i reformarbejdet studenterbevægelsens muligheder for at organisere aktioner i stil med dem i 1968.

Jeg vil også i dette essay bruge udviklingen på Sociologisk Institut ved Købernhavns Universitet, i resten af artiklen blot kaldt instituttet, som illustrativt eksempel. De sociologistuderenes kampe på instituttet skal tjene som eksempel for at vise, hvorledes de studerende udnyttede den tilkæmpede nye studieordning med projekt-, gruppearbejde og afløsningsopgaver til at få et helt andet samfundskritisk indhold i studiet - en helt ny slags sociologi med et klart samfundskritisk sigte, en fagkritisk sociologi. Kravet om kritiske studier var allerede på plakaten i 1968, men det tog tid at få realiseret kravet. Den gennemgående problemstilling i dette essay er at undersøge, hvordan det dengang lykkedes for de studerende at bruge den tilkæmpede indflydelse til at udvikle et helt nyt fagkritisk indhold i studiet, rettet mod en klar kritik af det borgerlige samfund. Men samtidig skulle det nye fagkritiske studie opfylde de formelle krav til en universitetsuddannelse.

Fagkritik var i studenteroprørets første fase en ekstern fagkritik, dvs. en kritik af sociale urimeligheder gennemført ved brug af et fags metoder og teorier og til støtte for grupper, der kæmpede for bedre vilkår i samfundet, oftest i samarbejde med fagforeninger. Mest kendt er nok Malerrapporten (1971), lavet i samarbejde med en gruppe malere for at vise, at de hjerneskader, som malere fik - malersyndromet - skyldtes det arbejde, de udførte hele dagen i en tåge af opløsningsmidler. Rapporten bidrog til en skærpet arbejdsmiljøregulering af malernes vilkår. Denne brug af eksisterende metoder og teorier til en kritik af forhold i samfundet viste samtidig begrænsningerne i den traditionelle videnskab, ikke mindst sociologi, når resultaterne skulle bruges til en samfundskritik. Det førrte til krav om en kritik af de eksisterende fags videnskabsteoretiske grundlag og funktion i samfundet, og her var marxistisk teori et vigtigt bidrag. Denne nye fagkritik fik navnet intern fagkritik. Det er denne fagkritik, der er temaet for essayet.

For at få et overblik over de mange kampe og konflikter på instituttet $\mathrm{i}$ perioden fra 1968 frem til begyndelsen af 1980'erne har jeg valgt at opdele 
kampen for et nyt samfundskritisk indhold i sociologistudiet $\mathrm{i}$ tre perioder. Opdelingen kan naturligvis diskuteres, og der er helt sikkert en række overlappende forløb, men denne opdeling af den lange periode er efter min overbevisning den bedste måde til beskrivelse af udviklingen i perioden.

I den første periode fra 1968 til 1969/70 handlede det for de studerende som nævnt om en kritik af den borgerlige sociologi som ideologi og at kunne arbejde kollektivt med fagkritiske projekter. Begge dele var en del af kampen for en ny studieordning, der netop skulle indføre gruppe- og projektarbejde. I anden periode fra 1970 til 1974/75 var dagsordenen den videre udvikling af en fagkritisk sociologi, baseret på et marxistisk grundlag og rettet mod at lave projekter med fagkritisk indhold, som også kunne bruges af folk udenfor universitetet. I den sidste periode fra 1974/75 til 1982/83 var strategien baseret på en marxistisk analyse af uddannelsessystemets funktion i den moderne kapitalisme. Det betød en sammentænkning af en kritik af de erhvervsfunktioner, som sociologer dengang varetog med marxistisk teori i den såkaldte dobbeltkvalificeringsstrategi.

\section{2. Årene 1968-1969/70}

»vi vil ikke længere finde os i en dårlig og autoritær katederundervisning, og inkompetente undervisere, men vi vil have en anden slags undervisning, en der aktivt inddrager os studerende og som vi kan bruge til at forholde os kritisk til samfundet.«

Dette citat fra en løbeseddel på Sociologisk Institut fra foråret 1968 udtrykker meget præcist baggrunden for de sociologistuderendes aktioner i 1968. Løbesedlen formulerede meget klart, at det handlede om kritik af autoritær og inkompetent undervisning og krav om medbestemmelse for at få en relevant samfundskritisk uddannelse. Den nye indflydelse, som Styrelsesloven nu gav mulighed for, blev især brugt til at få udviklet nye undervisningsformer, baseret på projekter valgt af de studerende og udført som gruppearbejde. Men der var også krav om et nyt indhold i sociologistudiet.

Kombinationen af nye og fleksible rammer for undervisningen gjorde det muligt for de studerende at arbejde med samfundskritiske projekter indenfor den nye studieordning, dvs. at kunne lave samfundskritik i gruppeprojekter, som samtidig kunne godkendes som eksamensopgaver. Der var i denne periode primært tale om en ideologikritik af den borgerlige sociologis funktion som den herskende klasses redskab. Den faglighed, som de daværende lærere havde som ideal, var en neutral positivistisk sociologi baseret på naturvidenskabelige metoder, hvis »objektive « resultater skulle bruges til at erstatte politiske løsninger af samfundsproblemer. Det er nok bedst formuleret af den amerikanske sociolog Georg Caper Lundberg, som havde inspireret lærerne 
på sociologi. Han definerede sin form for sociologi i sit programskrift »Kan videnskaben redde verden« på denne måde:

»Socialvidenskabsmænd vil snakke mindre og sige mere. De vil støtte sig stærkere til en knappere fremstillingsform, den statistiske og matematiske. Meget af det som nu går for samfundsvidenskab vil passende kunne overføres til andre ligeså agtværdige områder, såsom journalistik, drama og litteratur. Betragtet under dette synspunkt vil dette materiale være anvendeligt som propaganda, som nyhedsstof, som kunst og udløsning for menneskelige følelser.«(Lundberg 1965, s. 57).

For Lundberg og den amerikanske positivistiske tradition var alle andre sociologiske traditioner eller skoler, herunder fremtrædende europæiske traditioner som Frankfurterskolen, ikke samfundsvidenskab. Det provokerede naturligvis de sociologistuderende og motiverede dem til at kæmpe for at lære om andre sociologiske traditioner end den Lundberg'ske positivisme, i første omgang de kritiske europæiske sociologitraditioner. Senere blev det også til en systematisk læsning af Marx' kritik af den politiske økonomi. I begyndelsen var læsningen af den nye sociologi organiseret i studentergrupper, da der manglede relevante undervisere. Gennem hårde fagpolitiske kampe på instituttet lykkedes det at få godkendt en studieordning, hvor der var plads til samfundskritiske, endog marxistiske projektopgaver, herunder også magisterkonferenser, ${ }^{3}$ samt at få ansat nye undervisere. Opgaven var nu at skabe et nyt indhold i sociologistudiet, baseret på en kapitalismekritik, der kunne afsløre den traditionelle sociologis samfundsbevarende funktioner. Samtidig skulle den nye sociologiske indsigt bruges til at gøre den kritiske sociologi synlig i omverdenen ved at lave fagkritiske rapporter, der kunne påvise undertrykkelse og magtmisbrug i arbejdslivet. Det blev til en række fagkritiske rapporter.

Denne strategi var et resultat af politiske overvejelser i studenterbevægelsen efter sejrene i 1968/69 om, hvordan den nye magt i universitetets organer skulle bruges. En gruppe sociologistuderende begyndte i 1970 at udgive det marxistiske tidsskrift Kurasje, ${ }^{4}$ for derigennem at kunne udvikle og udbrede den samfundskritik, som studenteroprøret rejste. Nedenstående citat fra lederen i nr. 2/3 kan læses som en præsentation af studenteroprørets samfundskritik i forhold til samfundsvidenskaberne.

»Vores udgangspunkt finder man derfor udmøntet i studenterparolen: »Forskning for folket - ikke for profitten «. Men denne parole kan give anledninger til misforståelser. ... Forskning for folket er ikke en modideologi. Denne forskning må være en beskrivelse af de konkrete forhold, gjort forståelige gennem en sammenhængende teoretisk analyse, der bevæger sig ud over fænomenernes tilsyneladenheder, som ideologer- 
ne arbejder med og benytter sig af, uanset om disse ideologer er positivister eller gammelmarxister.«(Leder i Kurasje 2/3 1970, s. 1).

De studerendes indflydelse på uddannelserne skulle efter studenteroprøret ikke kun bruges til pædagogiske reformer, et nyt fagligt indhold i uddannelsen skulle gøre det muligt at arbejde med en kritik af det kapitalistiske samfund - en fagkritik. En af de store udfordringer for de aktionerende sociologistuderende efter 1968 var, at man med styrelseslovens nye medindflydelse på ganske kort tid skulle arbejde med at give sociologistudiet et nyt og mere omfattende fagindhold, et kompetencegivende fagindhold, som også skulle rumme en samfundskritik (fagkritik), hvor marxistisk teori havde en central rolle. Dertil kom, at det var nødvendigt efter 1968 også at få ansat nye undervisere til de omfattende forandringer af faget. Samtidig var instituttet i denne periode præget af hårde interne kampe med lærerstaben fra før 1968.

\section{3. $1970 / 71$ til $1974 / 75$}

Fra 1968 til begyndelsen af 1970'erne kæmpede de aktive sociologistuderende for at sikre de pædagogiske reformer på studiet. Fra begyndelsen af 1970'erne blev der ved siden af arbejdet på at udvikle et grundlag for nyt indhold i studiet - et indhold, der skulle understøttes af marxistisk samfundskritik og bruges til kritiske analyser af centrale samfundsproblemer. I disse år kom der i den europæiske studenterbevægelse flere marxistiske analyser af uddannelsespolitikkens rolle i de moderne kapitalistiske samfund. Et af de centrale bidrag var en analyse af uddannelsessektorens funktion i de moderne kapitalistiske samfund af Altvater og Huisken (1971). Bogens analyser fik stor betydning for en formulering af en uddannelsespolitik på et marxistisk grundlag i de mere radikale dele af studenterbevægelsen, både i Vesttyskland og Danmark. Studenterrådet ved Københavns Universitet tog denne analyses resultater op og udgav i 1973 en kritisk analyse af uddannelsespolitikken i Danmark, en analyse, som også omfattede studenterbevægelsens strategier, udgivet i bogen »Videnskab - Udannelse - Kapital«. Samme år udkom et særnummer af tidsskriftet Fagkritik med titlen »Videnskab og Kapital«. Disse analyser blev fulgt op på instituttet, hvor der blev lavet marxistiske analyser af de forskellige områder af borgerlig sociologis rolle i samfundet (arbejdsmarked, socialpolitik $\mathrm{mm}$.). Fokus var nu flyttet fra en mere ideologisk kritik af borgerlig sociologi til en forståelse af, hvorfor den borgerlige sociologi ikke kunne overskride sine begrænsninger. Det var en sociologi, der kunne registrere problemer i samfundet og pege på løsninger, vel at mærke løsninger, der kunne modernisere, men ikke udfordre de eksisterende magtforhold i samfundet. Den marxistiske kritik af den borgerlige sociologis rolle i samfundet udviklede sig efterhånden til det teoretiske udgangspunkt for en ny strategi for sociologistudiet, kaldt »dobbeltkvalificeringsstrategien«, dvs. en strategi for sociologistudiet, som betød, at de studerende skulle kombinere et kendskab til den borgerlige 
sociologi med en systematisk kritik heraf baseret på marxistisk teori. Fokus var nu på det forhold, at den borgerlige sociologi var en integreret del af det kapitalistiske samfund, og kritikken af den borgerlige sociologis analyser af aktuelle sociale konflikter og problemer blev grundlaget for den sociologiske fagkritik. Dobbeltkvalificeringsstrategien skulle muliggøre, at de studerende kunne arbejde med fagkritiske analyser på marxistisk grundlag som en del af sociologistudiet, samtidig med at de studerende opnåede relevante sociologiske erhvervskompetencer. På det grundlag blev dobbeltkvalificeringsstrategien en model for udformning af et nyt indhold i sociologistudiet, et indhold, som kom til at dominere studiet frem til midten af 1980'erne.

\section{Ekskurs om dobbeltkvalificeringsstrategien}

Det er vanskeligt så mange år efter at give et fuldstændigt billede af de mange fagpolitiske diskussioner, som dannede grundlag for strategien. Denne blev især udviklet i de emnegrupper, der siden begyndelsen af 1970'erne var vokset frem som en uformel, men bærende struktur i studiet. Emnegrupperne var organiseret efter vigtige politikområder, socialpolitik, arbejdsmarkedspolitik, uddannelsespolitik og imperialisme/udviklingsteori. De var efterhånden blevet det centrale forum for en fagkritik, der byggede på marxistisk teori. Nedenstående citat fra en programartikel af en af strategiens vigtigste talsmænd, Kurt Aagaard Nielsen, bringes her for at give en oversigt over de teoretiske argumenter, der var baggrunden for udformningen af det, der blev til dobbeltkvalificeringsstrategien:

»Det drejer sig derimod om at udstrække kritikken af den politiske økonomi til at omfatte de forhold i den samfundsmæssige totalitet, som kapitalens i egentligste forstand indre økonomiske væsen udfolder sig over i beherskende/tilegnende interesse. En marxistisk kritik af socialvidenskaben starter således med en indkredsning af denne som borgerligt åndsarbejde og ikke med en almen genstandsbestemmelse ... (s. 205).

Aagaard Nielsen fortsætter med sin kritiske analyse af den borgerlige sociologis samfundsmæssige rolle.

»For sociologien, der i en vis forstand repræsenterer kapitalens standpunkt overfor den sociale væren, skal denne beherskes, dvs. sociologien er det affirmatives standpunkt for hvem det ikkeaffirmative må historisk objektiveres - empirisk kausalforklares.« (Aagaard Nielsen 1980, s. 207). 


\section{5. $1974 / 75-1986 / 88$}

Fagkritik baseret på dobbeltkvalificeringsstrategien blev i denne periode grundlaget for sociologiuddannelsen i København. Strategien var samtidig et forsøg på at løse det dilemma, som studenterbevægelsen var løbet ind i: Hvordan kan man organisere en uddannelse, som retter sig mod en radikal samfundskritik, men som samtidig kan fungere indenfor rammerne af universitetssystemet, dvs. sikre, at de studerende får de nødvendige kvalifikationer til deres kommende erhvervsfunktioner? Strategien havde i begyndelsen stor opbakning blandt de aktive studerende, men den svandt efterhånden. Strategien stillede store krav til de studerende, men undervisningsressourcerne var knappe, og samtidig var det studenterpolitiske engagement blandt nye årgange studerende faldende. Tilsammen betød det, at det blev mere og mere vanskeligt at fastholde dobbeltkvalificeringsstrategien. Det manglende studenterpolitiske engagement i denne periode var ikke kun noget, der ramte sociologistudiet, det fandt sted på alle studier. På sociologistudiet kom det til udtryk ved, at mange af de nye studerende ikke fandt sig tilpas i den herskende dobbeltkvalificeringsstrategi. De var nu fanget i et dilemma, enten at deltage i den del af undervisningen, der var organiseret efter dobbeltkvalifikationsstrategiens principper, eller at deltage i de på det tidspunkt meget sporadiske andre undervisningstilbud. Det udløste en kritik, som i første omgang blev rettet mod mangler i strategien og krav om at revidere denne, men uden at diskussionen forholdt sig til strategiens forudsætninger. Det blev tydeliggjort i de studerendes blad Tigeren i 1978 med overskriften: »Fagkritikkens elendighed $\ll$.

»Denne strategi er undertiden blevet opfattet ret firkantet, således at der ingen sammenhæng var imellem de to kvalifikationsmængder. Hvis tingene ikke skal falde fra hinanden, så kræver det dels en udviklet fagkritisk erfaring, og et udviklet konkret kendskab til den anvendte socialvidenskab. Faktisk må vi indrømme, at ingen af disse forudsætninger har været tilstede.« (Abrahamson, 1978, s. 49).

Løsningen skulle være at sikre bedre sammenhæng mellem fagkritikken og den anvendte sociologi. Men der var flere uløste problemer bag den faldende tilslutning til strategien. Kurt Aagaard Nielsen svarede i samme nummer og pegede på et af problemerne. Teori- og skolingsudviklingen var mere og mere blevet løsrevet fra konkrete politiske aktiviteter.

»Universitetsinstitutionaliseringen har bevirket at fagkritiske projekter har fået en stærk universitær drejning - de er brutalt sagt blevet omdefineret til afløsningsopgaver og eksamensopgaver med mere eller mindre krystalliserede politiske formuleringer.« (Aagaard Nielsen, 1978, s. 52) 
Institutionaliseringen og fraværet af det nødvendige fagkritiske engagement var imidlertid ikke den eneste grund til dobbeltstrategiens manglende succes. Allerede i strategiens udgangspunkt lå et uløst problem. Når sociologien skal »repræsentere kapitalens standpunkt overfor den sociale væren som den skal beherske« (Aagaard Nielsen,1980, s. 207), efterlader det et centralt spørgsmål: Hvorledes kan denne tilgang til fagkritiske sociologiske analyser have adgang til viden om de former for sociale kampe, der ikke er underlagt kapitalforholdet, såsom klassekampe? Nedenstående citat fra et foredrag, som den tyske socialpsykolog Peter Brückner holdt i København i 1975, peger på en polemisk måde på problemet.

»Klassebevidsthed er endelig et udtryk for, at de arbejdende mennesker ikke kun er produkter af kapitalen. Den, der antager det og venter på den næste krise - den kommer uden tvivl - er ligesom den fulde, der slår armene om en plakatsøjle og løber rundt om den og skriger: Hjælp, jeg er omringet.« (Brüchner og Sichtermann 1975)

Klasseperspektivet blev et problem for dobbeltkvalificeringsstrategien i den forstand, at den borgerlige sociologi, der skulle beherske og kontrollere de sociale forhold, også repræsenterede kapitalens standpunkt overfor de sociale forhold. Det begrænsede denne sociologis problemområder og havde som konsekvens, at alt der ikke kunne indordnes under en kapitalistisk vareøkonomis rammer blev fraværende i den borgerlige sociologis perspektiver. Klasseperspektivet, der som udgangspunkt har, »at de arbejdende mennesker ikke kun er produkter af kapitalen «, var og er stadig ikke et fokusområde for den borgerlige sociologiske forskning, og det begrænsede på den måde de områder for den sociologiske fagkritik, som ellers skulle fremmes af strategien.

Det er på sin vis også en pointe, som den amerikanske sociolog C. Wright Mills allerede i 1958 havde fremført mod den etablerede sociologi i sin bog »The Sociological Imagination«. Wright Mills slutter bogen med følgende krav til den kritiske sociolog:

»Do not allow public issues as they are official formulated, or troubles as they are privately felt, to determine the problems that you take up to study. Above all, do not give up your moral and political autonomy by accepting in somebody else's terms the illiberal practicality of the bureaucratic ethos or the liberal practicallity of moral matters. Know that many personal troubles cannot be solved merely as troubles but must be understood in terms of public issues - and in terms of the problems of historymaking.«(Wright Mills 1961, s. 226). 
Dobbeltkvalificeringsstrategien havde vanskeligt ved at følge Brückners og Mills' krav om en konsekvent samfundskritisk sociologi, fordi strategien definerede sit empiriske udgangspunkt i den borgerlige sociologis resultater og kom derved utilsigtet til at nedtone det oprindelige mål: at levere en radikal samfundskritik! Tilløb til reformering af dobbeltkvalificeringsstrategien blev dog umuliggjort i slutningen af perioden, da en række tilknyttede undervisere blev fyret eller forflyttet i forbindelse med lukningen af Sociologisk Institut i midten af 1980 'erne.

\section{1980'erne og derefter}

Denne skitse af udviklingen i studenterpolitikken på instituttet fra 1968 til midten af 80'erne har skullet vise, hvorledes de studerende lige efter oprøret i 1968 tog kampen op, ikke blot for at få fjernet den autoritære katederundervisning, men også for at erstatte den med nye undervisningsformer, gruppearbejde og projekter. Forløbet viser også de vanskeligheder, som de studerende stod overfor. Kampen havde mere vidtrækkende perspektiver: de studerende ville også have et nyt og samfundskritisk indhold i studiet. De sociologistuderende forsøgte at løse denne problemstilling, først gennem en ideologikritik af sociologiens rolle og senere gennem en kritik baseret på marxistisk analyse af universitetsuddannelsernes funktion i den moderne kapitalisme. Det lykkedes i en periode at få en ny model for sociologistudiet til at fungere, en model, hvor læring af borgerlig sociologi havde udgangspunkt i en marxistisk analyse af uddannelsessystemets funktion i den moderne kapitalisme.

Men gennemgangen af forsøgene på at løse opgaven med at skabe en ny, samfundskritisk sociologiuddannelse peger også på de problemer, der var forbundet med at organisere en fagkritisk sociologiuddannelse. Dobbeltkvalificeringsstrategien havde de førnævnte faglige begrænsninger, men manglede også at tage hensyn til det forhold, at det fagkritiske arbejde i et studium havde og stadig har baggrund i et personligt fagpolitisk engagement hos den studerende.

De mange nye studerende, der søgte optagelse på studiet i slutningen af 1970'erne og frem, mødte et sociologistudie, der var organiseret efter dobbeltkvalificeringens principper og forudsatte, at de studerende havde den nødvendige motivation til den ekstra arbejdsindsats, som var forudsat i denne model for studiet. Det fagpolitiske engagement var tilstede hos de studerende i årene lige efter 1968, hvor der var en udbredt accept blandt de studerende for at arbejde med fagkritik. Men det var ikke en realistisk forudsætning i slutningen af 1970'erne. På instituttet var der ikke længere den samme opbakning til fagkritiske studier som tidligere, og det ramte også dobbeltkvalificeringsstrategiens model for fagkritik. En analyse af fagkritikkens status generelt fra begyndelsen af 1970'erne pegede allerede i 1972 på dette problem. 
»Fagkritikken var nu i en eller anden forstand blevet institutionaliseret og havde derved mistet den evne til at mobilisere nye studerende, som strategien oprindelig havde haft. Svaret fra de studenterpolitisk aktive var, at organisere sig med andre grupper udenfor universitetet ...« (Hansson et. al. 1972, s. 17).

Hele forløbet omkring udviklingen af en ny sociologiuddannelse med en teoretisk baseret samfundskritisk profil har vist, hvor vanskeligt det var at organisere studiet alene med det sigte at understøtte fagkritiske projekter. Strategien var meget hurtigt blevet institutionaliseret, uden at der blev taget det nødvendige hensyn til de studerende, der ikke alle havde samme fælles interesse i det fagpolitiske grundlag. Kampen for at få de pædagogiske reformer indført i studieordningen havde været en succes, men også krævet mange ressourcer. En konsekvens heraf var, at arbejdet med at planlægge og videreudvikle det faglige indhold i studiet blev mangelfuldt. Dertil kom mangel på undervisningsressourcer. Eksamen og færdiggørelse af studiet kom på den baggrund til at betyde mere og mere for et voksende antal studerende, og fagkritikken, som strategien skulle understøtte, gled i baggrunden.

Studenterbevægelsen søgte i den periode allierede udenfor universitetet for at få støtte i kampen for flere ressourcer og for fastholdelse af medbestemmelsen fra Styrelsesloven fra 1970. Men det politiske klima var forandret. Den støtte, som studenteroprøret i 1968 og årene lige efter havde haft i Folketinget - det var den radikale undervisningsminister Helge Larsen, som gennemførte den demokratiske styrelseslov i 1970 - var forsvundet. Gennem 1970'erne ændrede den politiske og administrative åbenhed overfor studenterbevægelsen sig. Som et eksempel på de forandrede politiske vinde skal her nævnes, at i 1975 besluttede den socialdemokratiske undervisningsminister Ritt Bjerregård at indsætte et eksternt rektorat på RUC og senere at bortvise demonstrerende studerende. I den forbindelse blev der i Folketinget rejst krav om at nedlægge RUC. Statslige nedskæringer og løbende begrænsninger af de studerendes medbestemmelse kunne i længden kun modvirkes af en politisk mobilisering på universitetet samt med allierede udenfor. Det politiske landskab var som nævnt forandret i forhold til årene lige efter 1968, og studenterbevægelsen kunne ikke længere mobilisere de studerende i samme omfang som tidligere.

\section{Erfaringer fra studenteroprøret!}

Kan man drage nogle konklusioner af denne fortælling? Den er nok baseret på, hvad der skete på sociologistudiet dengang, men det er rimeligt at antage, at de samme problemer mere eller mindre også var til stede på andre studier. De studerendes aktionsprægede kampe for en ny pædagogik og fagkritiske studier i 1968 fik i årene efter succes, og det betød, at de studerende mere og mere blev inddraget i det reformarbejde, som Styrelsesloven muliggjorde. En 
konsekvens var, at reformarbejdet integrerede de studerende i universitetets bureaukratiske organer. Det kan bedst beskrives som en institutionalisering. Det er ifølge organisationssociologien ofte en følge af en ikke planlagt inddragelse i et bureaukratisk system, men denne konsekvens af de succesfulde kampe kom dengang bag på de studerende. På længere sigt betød det en professionalisering af arbejdet i studenterorganisationerne og en ændring af aktionsformerne. Mange år senere beskriver jurastuderende Pernille Skipper i en artikel fra 2013 sine oplevelser som nyvalgt medlem af Studenterrådet ved Københavns Universitet i 2005 på følgende måde: »Kulturen i Studenterrådet indebar en tydelig præmis om, at politisk aktivitet og indflydelse fandtes i møder med beslutningstagere og i lobbyisme, hvis man skulle tages alvorligt.« (Skipper 2013, s. 141). Denne studenterpolitiske strategiændring har naturligvis også baggrund i de mange lovindgreb, som efterhånden har begrænset de studerendes indflydelse på universiteterne, men man skal ikke overse betydningen af ovennævnte inddragelse af de studerende i universitets og ministeriets bureaukratiske systemer.

Studenteroprørets sejre på sociologi (og på andre studier) betød som nævnt en stadig voksende deltagelse i det administrative og bureaukratiske universitetssystem, en deltagelse, som var en forudsætning for at kunne udnytte den vundne medbestemmelse. De studenteraktivister, der i 1970'ernes første år havde deltaget i råd og nævn som opposition og kæmpet for nye, radikale studieordninger, og for studenterindflydelse på studierne, skulle nu forsøge at løse problemer med beskæring af ressourcer og andre bureaukratiske indgreb. Problemet var som nævnt, at der ikke længere var den samme aktive og kæmpende studenterbevægelse, som kunne have støttet de lokale aktivistiske studenter i råd og nævn.

Men det skal ikke skygge for det forhold, at studenteroprøret i 1968 og årene derefter i et komplekst samspil med det politiske system opnåede en række afgørende resultater, ikke mindst en pædagogisk revolution af den traditionsbundne undervisning og - i en periode - en demokratisering af universiteterne.

Det er her godt 50 år efter ikke muligt at få øje på, at der dengang var en klar og overordnet strategi fra nogen af siderne, hverken fra den statslige side eller fra studenterbevægelsen. Skiftende regeringer havde i 1960'erne nedsat flere vigtige udvalg, hvis opgave var at reformere universiteterne (Hansen 2017), men disse udvalg havde ikke fået deres forslag om reformer på universiteterne gennemført. Studenterbevægelsen aktionerede godt nok for medbestemmelse under fælles paroler, men uden en klar langsigtet strategi. Dertil kom, at bevægelsen i begyndelsen bestod af en række ganske selvstændige lokale bevægelser eller studentergrupperinger på de studier, hvor lokale forhold havde stor betydning for, hvorledes de studerende aktionerede. Organisationssociologien har et begreb, som kan bruges til at beskrive forandringer $\mathrm{i}$ en organisation, hvor man ikke kan se, at forandringer følger en fastlagt 
strategi. Det er begrebet »garbage can«, som blev introduceret af James P. March og Johan G. Olsen (1982). Begrebet er en kritik af teorier om en entydig sammenhæng mellem strategier og organisationsudvikling og bruges til at beskrive forandringer, der ikke følger en overordnet strategi, men tværtimod er et uforudsigeligt resultat af en række såvel tilsigtede som utilsigtede aktioner og beslutninger

»Forløbet af en reorganisering synes således at afhænge mindre af egenskaberne ved reorganiseringsforslagene eller bestræbelserne, end af tilfældigheder omkring den kortsigtede politiske opmærksomhed, som grupperingerne omkring reorganiseringen typisk har meget lidt kontrol over. ... Sammenhængen mellem disse elementer synes at være et produkt mere af deres samtidighed end af deres indhold.« (March og Olsen 1982; s. 285).

Studenteroprørets dynamik svandt langsomt, da der ikke længere var tilslutning til at lave omfattende aktioner og demonstrationer og samtidig var de studerende gennem Styrelsesloven blevet integreret i universitetets system. Oprøret var på en måde blevet »indkapslet « gennem sine sejre og havde fået indflydelse indenfor systemet. Denne »indkapsling « begrænsede bevægelsens muligheder for at lave samme slags aktioner som i 1968 og dermed mulighederne for at kæmpe imod den løbende tilbagerulning af de reformer, som kampene i 1968 havde skaffet. Dertil kom, at studenteroprøret havde muliggjort - helt klart utilsigtet - helt nye politiske og centraladministrative adgange til at gribe regulerende ind i de hidtidige autonome universiteter, ikke mindst gennem oprettelsen af Direktoratet for de videregående Uddannelser (DVU) i 1974. ${ }^{5}$ Men studenteroprøret i 1968 fik stor indflydelse på hele samfundet gennem sit radikale opgør med det elitære universitets traditioner. Mest synligt i dag er nok studenteroprørets centrale rolle i udviklingen af nye undervisningsformer, gruppe- og projektarbejde, som snart bredte sig langt udenfor universiteterne.

I dette essay har jeg undersøgt de sociologistuderendes kampe for at lave en helt ny sociologiuddannelse over en periode på ca. 10 år. Denne kamp havde to sider, en kamp for at skabe nye åbne rammer for den pædagogiske fornyelse i form af ændringer i studiebekendtgørelser gennem brug af deltagelse i råd og nævn. Parallelt med denne kamp forsøgte de studerende gennem fagpolitiske diskussioner at få formuleret et nyt, fagkritisk indhold i uddannelsen. Den sidste kamp har været udgangspunkt for dette essay.

\section{Slutning}

Har denne fortælling om de sociologistuderendes kamp om at lave en ny og radikalt anderledes sociologiuddannelse interesse i dag? Kampene for et nyt indhold i studiet fortæller en del af historien om fagets udvikling siden 
1960'erne. Behovet for en kritisk holdning til indholdet i enhver samfundsvidenskabelig universitetsuddannelse fremhævede C. Wright Mills allerede i 1958 i »The Sociological Imagination«. Wright Mills kritiserede tendenserne til stadig snævrere fagspecialisering i samfundsvidenskaberne, og det gjorde han ved at fremhæve disse fags oprindelige tradition for samfundskritik.

»The sociological imagination enables us to grasp history and biography and the relations between the two within society. That is its task and promise. To recognize this task and this promise is the mark of the classic social analyst. It is the characteristic of Herbert Spencer - turgid, polysyllabic, comprehensive; of E.A. Ross v- grateful, muckraking, upright, of August Comte and Emil Durkheim, of the intricate and subtle Karl Manheim. It is the quality of all that is intellectual excellent in Karl Marx; it is the clue to Thorstein Veblens brilliant and ironic insight ... (s. 6).

Dobbeltkvalificeringsstrategien på Sociologisk Institut havde som intention at understøtte en sådan samfundskritik, men blev over tid en for snæver model for sociologiuddannelsen og kunne i længden ikke omfatte »The Sociological Imagination «. Mangel på undervisere og hårde interne fagpolitiske kampe blokerede for en nødvendig reform af strategien. Efter en årrække var denne strategi ikke længere tiltrækkende for nye studerende. Kampen for et nyt fagkritisk indhold i sociologiuddannelsen blev således ikke en succes i den forstand, at resultatet blev et nyt og varigt indhold i studiet, dertil havde modellen et for snævert teoretisk grundlag, og den tog ikke hensyn til spørgsmålet om fagpolitisk engagement hos de studerende. Men kampen viste på den anden side det potentiale, der er hos de studerende, som engagerer sig i kampen for at forandre deres studie. Det er de studerende, der oplever fejl og mangler i uddannelsen og derved kan motiveres til at kæmpe for forandringer. Læren af denne historie er, at aktive studerende kan kæmpe for grundlæggende forandringer i deres studier og opnå resultater. Men konstruktive og varige ændringer af fagindholdet i et studie kræver en lang kamp, en bred mobilisering af de studerende og reelle muligheder for indflydelse (medbestemmelse). Det gælder ikke mindst, når der, som i denne historie om dobbeltkvalificeringsstrategien, også er tale om, at faget skal have en klar samfundskritisk profil. Dertil kom, at strategien var ganske idealistisk, da den forudsatte, at de studerendes motivation i længden kunne holde til strategiens krav om en »dobbelt« studieindsat. Ikke alle disse forudsætninger var til stede, og strategien kunne i længden ikke fungere som en selvstændig model for sociologistudiet.

Vil studerende kunne tilkæmpe sig til en tilsvarende radikal uddannelsesreform i dag? Flere forhold har ændret sig siden årene efter 1968. Dengang var der en stærk studenterpolitisk mobilisering, som i stort omfang og med 
succes anvendte de muligheder for studiereformer, som Styrelsesloven dengang muliggjorde. Dertil kom, at der i samme periode var en politisk og administrativ åbenhed overfor reformer på universiteterne, noget, som velfærdsstatens politiske »arkitekter « længe havde ønsket. Disse forhold tilsammen bidrog til, at de studenterpolitiske visioner, ofte inspireret af Oscar Negts bog »Sociologisk fantasi og eksemplarisk læring « (1980), kunne realiseres. Ovennævnte forudsætninger for studiereformer er ikke til stede i dagens universitetsverden. Men der er måske andre forhold, der kan tælle på plussiden? Universitetsundervisningen er i dag i høj grad præget af det projektorienterede gruppearbejde, som var en af studenteroprørets sejre. Dertil kommer, at modstand mod forandringer blandt universitetslærere næppe er så indædt, som den var dengang blandt de meget konservative professorer, og trods mange års demontering af Styrelsesloven har studerende stadig 50 \% af pladserne i studienævnene.

Dette essay og min bog fra 2018 handler begge om studenteroprøret, især om hvad der dengang skete på Sociologisk Institut, og forsøger at vise, at radikale forandringer af universitetsfagenes indhold primært kommer fra de studerende, ikke fra ministerielle arbejdsgrupper eller fra lærerne. På plussiden, i kampen for at de studerende i dag kan komme igennem med reformer, er, at der politisk ser ud til at være interesse for reformer i universitetsuddannelserne, sådan at de kan tilpasses det videnssamfund, der er på vej. Men brug af en sådan mulighed kræver, at de studerende går aktivt ind i kampen for at opnå de forandringer, de selv ønsker. Men måske kan dagens studerende også inspireres af Oscar Negts sociologiske fantasi.

\section{Noter}

1. Hvor jeg i bogen om studenterbevægelsens kamp om politisk indflydelse på undervisningen kunne trække på en række dokumenter, ikke mindst i Rigsarkivet, bygger den efterfølgende analyse på et meget ringere dokumentmateriale og er af den grund blevet suppleret med mine personlige erfaringer fra Sociologisk Institut. Stort set alle interne fagpolitiske diskussioner blev dengang formidlet i maskinskrevne oplæg, som blev mangfoldiggjort på duplikator og evt. trykt i de sociologistuderendes eget blad »Tigeren«. Bladet og andre af dokumenterne fra perioden findes ikke i Rigsarkivet, og jeg har selv kun et begrænset antal af disse dokumenter.

2. Universiteternes styrelseslov (Lov nr. 271 af 5. juni 1970), kommenteret udgave ved Knud Espen Hansen (1970). Gyldendal, København.

3. Jan Kirstein har samlet en komplet oversigt over sociologiske magister og kandidatafhandlinger fra 1967 til 1987.

4. Alle tidsskriftets 38 numre er tilgængelig på nedenstående webadresse: https://rauli.cbs. $\mathrm{dk} /$ index.php/kurasje

5. Se nærmere herom hos Hansen, Else (2017), Bredsdorff, Nils (2008) og Åkerstrøm Andersen, Niels (1995). 


\section{Litteratur}

Aagard Nielsen, Kurt (1980); »Åndsarbejde og videnskabskritik«. Kurasje nr. 23-24, 1980: 185-217, København. https://doi.org/10.22439/kur23-2419803750

Aagaard Nielsen, Kurt (1978); Tigeren November 1978. Tigersocietetet, Rosenborggade 15, Sociologisk Institut, København.

Aagaard, Nielsen Kurt (1976); Introduktionspjese til Sociologisk Fagfront, februar, s. 20. Tigersocietetet, Rosenborggade 15. Sociologisk Institut, København.

Abrahamson, Peter (1978); Tigeren November 1978. Tigersocietetet, Rosenborggade 15. Sociologisk Institut, København.

Altvater, Elmar und Huisken, Freek (1971); Materialien zur politischen Ökonomie des Ausbildungssektors, Erlangen.

Bredsdorff, Nils (2008); Universiteternes styrelse, ledelsens styrkelse og forskningens frihed. Essays om universitetspolitikken og universiteternes historie. Skriftserie fra Roskilde Universitetsbibliotek, nr. 51, Roskilde. https://doi.org/10.7146/politica.v26i2.67838

Brückner, Peter og Sichterman, Barbara (1975); Klassebevidsthed og konjunkturcyklus. Bearbejdet udgave af foredrag holdt 21.3. i København. Tigersocietetet, København. https://doi. org/10.22439/kur1219753678

Fagkritik særnummmer 1: Videnskab \& Kapital. 1973. Modtryk, Århus.

Hansen, Else (21017); Profesorer, Studenter og Polit.er. Om velfærsstatens universitetspoltik 19501975. Museum Tusculanums Forlag, København.

Hansson, Finn (1968); Studenteroprør og Undervisningsrevolution. En fortælling om opgøret med traditionel universitetsundervisning: Roskilde Universitetsforlag 2018, Roskilde.

Hansson, Finn, Kirstein, Jan, Larsen, Bernhard og Aagaard Nielsen, Kurt. (1972); Studenterbevægelsen: fra studenteroprør $i 68$ til fagkritik $i$ 72. 2. interne fagkritiske text. Tigersocietetet, Rosenborggade 15: København. https://view.publitas.com/p222-10496/studenterbevaegelsen/page/1

Kirstein, Jan (1988); Sociologiske magister- og kandidatafhandlinger. En 20 års bibliografi. Sociologisk Institut, København.

Leder, Kurasje nr. 2/3, s. 1. (1970).

Lundberg, George (1965); Kan videnskaben redde os? Hans Reitzel, København.

Malerrapporten: en foreløbig rapport om sundhedsfarerne i malerfaget. (1971). Modtryk, Århus.

March, James G., Johan P. Olsen (1979); Ambiguity and choice in Organizations. Universitetsforlaget: Her citeret efter James March (1995), Fornuft og forandring I organisationer, Frederiksberg.

Negt, Oscar (1981); Sociologisk fantasi og eksemplarisk indlæring. Kurasje, København.

Negt, Oscar (2019); Dannelse og Demokrati. Frydenlund, København.

Skipper, Pernille (2013); 3procent-netværket - Studenterrådets uægte barn, i Johansen Meisner, Jesper (red.); Enhed og Interesse, En bog om Studenterrådet ved Københavns Universitet 1995-2012. Studenterrådet ved Københavns Universitet, København. https://doi.org/10. 1080/03461238.1935.10405836

Studenterrådet ved Københavns Universitet (1973); Videnskab - Uddannelse - Kapital. Rekonstruktionen af det borgerlige universitet - en kritik. Nyt fra Samfundsvidenskaberne, København. 
Tigeren - diverse numre. Fagfronten, Sociologisk Institut, København.

Wright Mills, C. (1959); The Sociological Imagination. First Evergreen Edition, Grove Press, New York.

Åkerstrøm Andersen, Niels (1995); Selvskabt forvaltning. Forvaltningspolitikkens og centraladministrationens udvikling i Danmark 1900-1994. Nyt fra Samfundsvidenskaberne, København. https://doi.org/10.7146/politica.v32i3.68399 